\title{
COMPARISON OF MATHEMATICAL REASONING OF SMP STUDENTS BETWEEN LEARNING USING A REALISTIC APPROACH WITH OPEN ENDED APPROACH
}

\author{
Fathoni Akhmad Ramdhani ${ }^{1}$, Euis Eti Rohaeti ${ }^{2}$, Rosalina Rolina $^{3}$ \\ ${ }^{1,2,3}$ IKIP Siliwangi, Cimahi \\ ${ }^{1}$ fathoniahmadramdhani@gmail.com, ${ }^{2}$ e2rht@yahoo.com, ${ }^{1}$ maezarou@ gmail.com
}

Received: Aug $1^{\text {st }}, 2018$; Accepted: Oct $1^{\text {st }}, 2018$

\begin{abstract}
This study aims to examine whether improving students' mathematical reasoning abilities that get learning by using a realistic mathematics education approach is better than students who get open ended learning. Method in this research is experiment method by using 2 sample. The sample was taken randomly, that is class VIII-C as a class that get learning by using realistic mathematics education approach, and class VIII-B as a class that get open ended learning. Instrument in this research is a test instrument in the form of description consists of 8 given problem in the form of pretest and postes, then the data of students' mathematical reasoning scores were analyzed by using the normality test of both groups then tested the homogeneity of two variance and the significance test of the difference of two averages. The final result of this study with a significance level of 0.05 concluded that the improvement of capability the mathematical reasoning of students who get learning by using a realistic mathematics education approach is better than students who get open ended learning.
\end{abstract}

Keywords: reasoning ability, realistic and open ended math approach.

\begin{abstract}
Abstrak
Penelitian ini bertujuan untuk menelaah apakah peningkatan kemampuan penalaran matematis siswa yang mendapatkan pembelajaran dengan menggunakan pendekatan pendidikan matematika realistik lebih baik daripada siswa yang mendapatkan pembelajaran open ended. Metode dalam penelitian ini adalah metode eksperimen dengan menggunakan 2 sampel. Sampel diambil secara acak, yaitu kelas VIII-C sebagai kelas yang mendapatkan pembelajaran dengan menggunakan pendekatan pendidikan matematika realistik, dan kelas VIII-B sebagai kelas yang mendapatkan pembelajaran open ended.Instrumen dalam penelitian ini adalah instrumen tes berbentuk uraian terdiri dari 8 soal yang diberikan dalam bentuk pretes dan postes, kemudian data skor kemampuan penalaran matematis siswa tersebut dianalisis dengan menggunakan uji normalitas kedua kelompok kemudian diuji homogenitas dua varians dan uji signifikansi perbedaan dua rata-rata.Hasil akhir dari penelitian ini dengan taraf signifikansi 0,05 menyimpulkan bahwa peningkatan kemampuan penalaran matematis siswa yang mendapatkan pembelajaran dengan menggunakan pendekatan pendidikan matematika realistik lebih baik daripada siswa yang mendapatkan pembelajaran open ended.
\end{abstract}

Kata kunci :kemampuan penalaran, pendekatan matematika realistic dan open ended.

How to Cite: Ramdhani, F.A., Rohaeti, E.E., \& Rolina, R. (2018). Comparison of Mathematical Reasoning of SMP Students Between Learning Using A Realistic Approach with Open Ended Approach. JIML, 1 (3), 329-334.

\section{INTRODUCTION}

Education is the most important factor of the development and development of a nation. Through education the creation of quality human resources. But, creating a quality Human Resources (HR) quality is not as easy to imagine. Many problems related to education, as 
330 Ramdhani, Rohaeti, \& Rolina, Comparison of Mathematical Reasoning of SMP Students between Learning Using a Realistic Approach with Open Ended Approach

proposed by Zulkardi (Abdul, 2005). 'The main problem in education in Indonesia is the low level of student learning outcomes in schools.' It explains that the human resource flaws we have. With various ways the government proclaimed the work program in education but also various things that become a barrier factor for the smooth performance. Education is one important aspects that will determine the quality of life of a person and a nation (Rahmi, Nadia, Hasibah, \& Hidayat, 2017).

In the Third International and Science Study (TIMSS) in 2007 reported that the average score of Indonesian maths level 8 (level II SLTP) is far below the average international math score and is ranked 36 out of 48 countries. According to Sastrosudirjo (Abdul, 2005), students' reasoning abilities consist of general reasoning, the ability to deduce and the ability to see relationships in which not only the relationship between objects but also the relationships between ideas and then use them to get other ideas'.

From the above explanation then the problem that arises is how the teacher chooses the appropriate learning model to develop the reasoning ability. To implement the learning, there are many learning models that can be used. So the authors propose learning using approachopen ended and learning by using realistic approach, known as "Realistic Mathematics Approach (RME)" as its solution.

In learning with open ended approach, students are expected not only to get answers but more emphasis on the search process an answer. According to Suherman (2003), argued that in the mathematical activities and activities of students is called open if it meets the following three aspects of student activities should be open, mathematical activities are a variety of thinking, and student activities and mathematical activities is a unity. The advantage of Open-Ended learning is that students have more opportunities to utilize comprehensive knowledge and mathematical skills.

According to (Suherman, 2003), said that in realistic learning students' ability to research activities (inquiry) trained and familiarized through guidance, so that students are able to find a pattern or concept kontruksivis. This is in line with the notion of reasoning is a process of thinking that is done in a way to draw general conclusions can be from individual cases but can also be contrary from the general to individual cases.

Freudenthal (Anggraeni, 2011) says that mathematics is a human activity. With a realistic approach, mathematics is not only a place to transfer material from teacher to student, but where students rediscover ideas and mathematical concepts through exploration of real problems.

The results of the research in the Approach of Indonesian Realistic Mathematics (PMRI) such as Fauzan (2002) on the implementation of learning materials for broad topic and around the fourth grade of elementary school in Surabaya show that realistic mathematical approach can be used in mathematics learning, Armanto (2002)on the development of learning paths of local multiplication and distribution with a realistic approach in primary schools in two cities whose results are more or less the same as those reported by Armanto (2002) who conducted research in Yogyakarta by taking samples of Secondary School (SLTP) students found positive, motivated, active, and creative outcomes of students.

From the concepts that relate between reasoning with the open-ended approach, the realistic mathematical approach, and the narrative of experiences already mentioned above, the researcher will conduct a study entitled "Comparison of Mathematical Reasoning between Students of the Learning Using Realistic Approach to Using the Open Approach Ended ". The following is an explanation of mathematical reasoning abilities and realistic approaches: 


\section{The ability of mathematical reasoning}

Reasoning is one of the basic mathematical competencies in addition to understanding, communication and problem solving. Reasoning is also a mental process in developing the mind of some fact or principle. According to Shutter and Pierce (Abdul, 2005), 'reasoning as a translation of reasoning can be defined as the process of achieving logical inference based on relevant facts and resources'. Suherman and Winataputra (Abdul, 2005) define mathematical reasoning as a process of thinking which is done in a way to draw general conclusions from individual cases but also from the general to individual cases.

The characteristics of reasoning are (1) the existence of a mindset called logic. In this case it can be said that reasoning activity is a logical process of thinking. This logical thinking is defined as thinking according to a certain pattern or according to certain logic; (2) the thought process is analytic. Reasoning is an activity that relies on an analytic, in the framework of thinking used for the analytical reasoning logic is concerned.

Mathematical reasoning that includes the ability to think logically and systematically is the highest cognitive domain of mathematics. Sumarmo (2014) provides an indicator of ability that includes the ability of mathematical reasoning, as follows: Make an analogy and generalization; Provide an explanation using the model; Using patterns and relationships to analyze Mathematical situations; Compile and test conjecture; Check the validity of arguments; Establish direct proof; Establish indirect proof; Give examples of deniers; and Following the rules of reference.

\section{Realistic Approach}

a. Understanding Realistic Approach

1) Understanding the realistic approach according to Sofyan (zahra, 2014), 'an educational approach that seeks to place education on the essential nature of education itself'.

2) According to Sudarman Benu (zahra, 2014), 'realistic approach is an approach that uses real-world situation problems or a concept as a starting point in learning mathematics'.

3) Realistic math that has been applied and developed in the Netherlands his theory refers to the mathematics that must be associated with reality and mathematics is a human activity.

4) In learning through a realistic approach, student information strategies evolve as they solve problems in familiar situations they have acquired, and they are the starting point for realistic learning (Realistic Mathematic Education (RME) learning. This is intended to make learning meaningful for students.

5) Realistic Mathematic Education (RME) is a teaching approach that starts on the real thing for students. This theory emphasizes process skills, discussions and collaborations, argues with classmates so that they can find themselves (Student Invonting), as opposed to Teaching Telling and ultimately students use that math to solve problems either individually or in groups.

6) In the Realistic approach the role of the teacher is nothing more than a facilitator, moderator or evaluator. While students think, communicate their arguments, classify their answers, and practice mutual respect for other people's strategies or opinions.Pendekatan Open Ended

\section{b. Understanding Open-Ended Approach}

According to Suherman (2003), the problem that is formulated to have the correct answer is called an incomplete problem or also called Open-Ended problem. Students who are faced with an Open-Ended problem, the main purpose is not to get an answer but to emphasize on how to arrive at an answer. Thus it is not just one approach or method of getting answers, but some or many. 
332 Ramdhani, Rohaeti, \& Rolina, Comparison of Mathematical Reasoning of SMP Students between Learning Using a Realistic Approach with Open Ended Approach

The "openness" of a problem is said to be lost if there is only one way of answering the given problem or there is only one possible answer to the problem. An example of applying OpenEnded problems in learning activities is when students are asked to develop different methods, approaches or approaches in answering the given problem rather than being oriented towards final (final) answers.

Learning with Open-Ended approach begins by giving students an open problem. Learning activities should lead and bring students in answering the problem in many ways and perhaps also with many answers (correct), thus stimulating the intellectual ability and experience of students in the process of discovering something new.

The purpose of learning Open-Ended problem according to Nohda (Suherman, 2003) is to help develop creative activities and mathematical mindset of students through the problem of posting simultaneously. In other words, creative activities and students' mathematical mindset should be developed to the maximum extent possible according to the ability of each student.

The Open-Ended Approach promises an opportunity for students to investigate strategies and ways of believing in their ability to elaborate on issues. The goal is no other is that the ability to think mathematics students can develop optimally and at the same time creative activities of each student communicated through the learning process. This is the main idea of learning with Open-Ended, which is learning that build interactive activities between mathematics and students to invite students to answer the problem through various strategies.

\section{METHOD}

The method in this research is experimental method, because there is manipulation of treatment, where one class gets its learning which uses realistic approach and in second class gets its learning using open ended approach, at the beginning and end of the learning both classes are given test so that the research design is as follows :

$$
\begin{aligned}
& \mathrm{A} \mathrm{O} x_{1} \mathrm{O} \\
& \mathrm{A} \mathrm{O} x_{2} \mathrm{O}
\end{aligned}
$$

Where
A: Classroom random sampling
O: Pre test / post test
$\mathrm{x}_{1}$ : Learning by using a realistic approach
$\mathrm{x}_{2}$ : Learning using the open ended approach

\section{Population and Sample Research}

The population in this study is all students of Junior High School (SMP) while the sample is taken 2 classes randomly where the one class becomes experimental class I, and the other class become experimental class II. The sample in this study is class 2A SMP, as experimental class I and class 2B SMP as experimental class II. The reason for choosing a sample is to be able to represent junior high school students in general.

\section{RESULTS AND DISCUSSION \\ Results}

Recapitulation of research result of students' mathematical reasoning ability among the learning using Realistic Mathematics approach with using open end approach is presented in the following table:

Table 1. Recapitulation of Research Results of Student Mathematical Reasoning Ability

\begin{tabular}{lllll}
\hline & \multicolumn{2}{l}{ Experiment } & \multicolumn{2}{l}{ Experiment Class } \\
& Class I & & II & \\
\cline { 2 - 5 } & Pretest & Posttest & Pretest & Posttest \\
\hline $\mathrm{n}$ & 30 & 30 & 30 & 30 \\
\hline
\end{tabular}




\begin{tabular}{lllll}
\hline $\mathrm{X}$ & 14.77 & 27.6 & 12.2 & 25.37 \\
\hline $\mathrm{s}$ & 3.32 & 1.99 & 2.67 & 2.68 \\
\hline
\end{tabular}

Furthermore, will be analyzed data postes to determine whether there are differences in students' mathematical reasoning abilities of experimental class I with experimental class II. The test to be performed is T test (difference of two averages). Here are the results of posttest data analysis:

Table 2. The Result of t Test Data Posttest

\begin{tabular}{|c|c|c|c|c|c|c|c|}
\hline Kls & $\mathrm{N}$ & - & S & $\begin{array}{l}\mathrm{T} \\
\text { hit }\end{array}$ & $\begin{array}{l}\text { P- } \\
\text { Value }\end{array}$ & DF & Interpretasi \\
\hline Eks1 & 30 & 14,70 & 2,18 & \multirow{2}{*}{5,31} & \multirow{2}{*}{0,000} & \multirow[b]{2}{*}{58} & \multirow{2}{*}{$\mathrm{H}_{0}$ ditolak } \\
\hline Eks2 & 30 & 11,80 & 2,04 & & & & \\
\hline
\end{tabular}

From the data it is seen that the significance value of two for the assumed equal variances is 0.000. Because the significant value is less than 0.05, this means that the ability of mathematical reasoning of students who get learning by using a realistic mathematical approach is better than students who received learning using an open ended mathematical approach.

\section{Discussion}

The results of the above study indicate that learning with a realistic mathematical approach gives a better impact than the open ended approach. Zaini, \& Marsigit (2014) reveal that realistic mathematical approaches are better at improving students' mathematical reasoning abilities. Wibowo (2017) reinforces that this realistic approach has a more effective influence on students' mathematical reasoning abilities, learning achievement, and learning interest.

Learning with a realistic mathematical approach has a significant effect on mathematical abilities, one of them is mathematical reasoning ability. Tandililing (2010) said that realistic mathematical approaches are realistic and constructive so they can help develop students' cognitive abilities.

In open ended learning, students are immediately confronted with problems that must be solved. For students who have good abilities, this is not a problem. But it is not necessarily applicable to students who are moderate or less capable. This causes the need for a construction process starting from something tangible. Here are the advantages of a realistic mathematical approach.

\section{CONCLUSION}

Based on the results of research and observation of authors in the field, this happens because the factors as follows:

a. The results of this study indicate mathematics learning by using a realistic mathematical approach has good potential to improve students' mathematical understanding of MTs because it is supported by visual aids that are easy to recognize and close to student environment. This learning model directs students to know the information or material being discussed, able to question themselves by looking directly or imagine a real object in their environment and describe in their own words to understand the material presented, and able to compare, differentiate the solution more likely to solve the problem.

b. Students whose learning uses a realistic mathematical approach are stimulated to understand the guidance of the LKS, finding solutions to any problems in the LKS and determining appropriate choices or answers on the basis of their own thinking, this can 
334 Ramdhani, Rohaeti, \& Rolina, Comparison of Mathematical Reasoning of SMP Students between Learning Using a Realistic Approach with Open Ended Approach

stimulate a large mindset and curiosity so that meaningful learning process will be more bigger hearing than learning to accept.

Unlike the case with students who in the learning using open-ended approach that tends to only accept the material by making their own learning.

c. Attention or concentration power and imagination of students whose learning using realistic mathematical approach is more honed than students whose learning using open ended approach.

d. Group discussions broaden the thinking space in developing ideas and creativity of thought as well as freedom in conveying any opinions among individuals and even between groups.

\section{REFERENCES}

Abdul. (2005). Kemampuan Penalaran Matematik Siswa SMP. Bandung: Tarsito Bandung.

Anggraeni, A. (2011). Perbandingan penalaran matematik siswa antara yang menggunakan pendekatan realistic dengan yang menggunakan pendekatan open ended. Pendidikan Matematika STKIP Siliwangi Bandung.

Armanto, D. (2002). Teaching Multiplication and Division Realistically in Indonesian Primary School: A Prototype of Local Instructional Theory. University of Twente.

Fauzan, A. (2002). Applying Realistic Mathematics Eduacation (RME) in Teaching Geometry in Indonesian Primary Schools. Univeristy Of Twente.

Rahmi, S., Nadia, R., Hasibah, B., \& Hidayat, W. (2017). The Relation Between Self Efficacy Toward Math With The Math Communication Competence. Infinity Journal, 6, 177182.

Suherman, E. (2003). Evaluasi Pembelajaran Matematika. JICA: Universitas Pendidikan Indonesia.

Sumarmo, U. (2014). Berpikir dan Disposisi Matematik Pembelajarannya. Bandung: Jurusan Pendidikan Matematika UPI.

Tandililing, E. (2010). Implementasi Realistic Mathematics Education (RME) di Sekolah. Jurnal Guru Membangun, 25(3).

Wibowo, A. (2017). Pengaruh Pendekatan Pembelajaran Matematika Realistik dan Saintifik terhadap Prestasi Belajar, Kemampuan Penalaran Matematis, dan Minat Belajar. Jurnal Riset Pendidikan Matematika, 4(1), 1-10.

zahra. (2014). Mengajar Matematika dengan Pendekatan Realistik.

Zaini, A., Marsigit, M. (2014). Perbandingan Keefektifan Pembelajaran Matematika dengan Pendekatan Matematika Realistik dan Konvensional Ditinjau dari Kemampuan Penalaran dan Komunikasi Matematik Siswa. Jurnal Riset Pendidikan Matematika, 1(2), 152-163. 